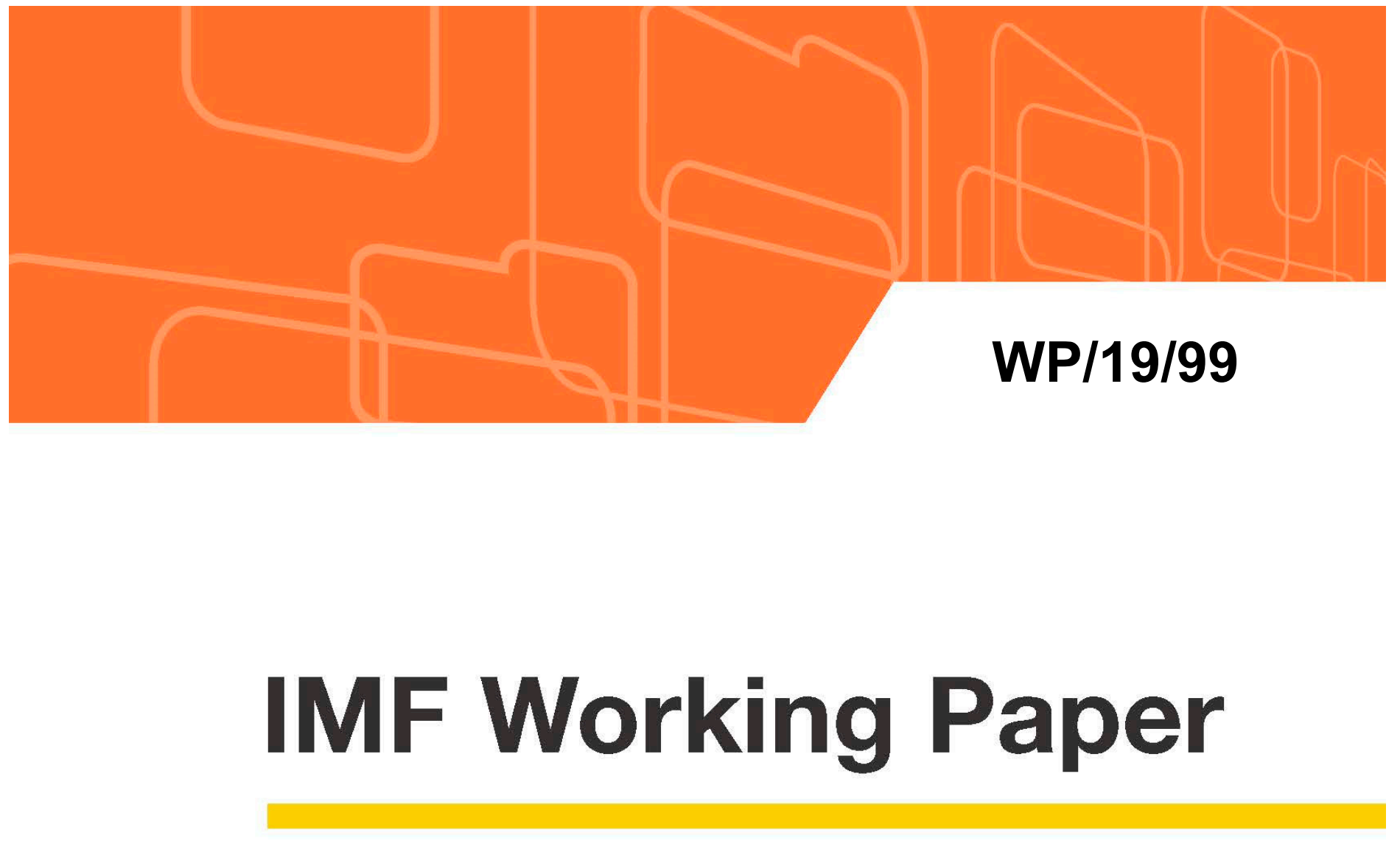

\title{
Can Contingent Convertibles Help Private Asset Managers Fund their Acquisition of Nonperforming Loans from Portuguese Banks?
}

by André Oliveira Santos

IMF Working Papers describe research in progress by the author(s) and are published to elicit comments and to encourage debate. The views expressed in IMF Working Papers are those of the author(s) and do not necessarily represent the views of the IMF, its Executive Board, or IMF management. 


\title{
IMF Working Paper
}

European Department

\section{Can Contingent Convertibles Help Private Asset Managers Fund their Acquisition of Nonperforming Loans from Portuguese Banks?}

Prepared by André Oliveira Santos ${ }^{1}$

Authorized for distribution by Alfredo Cuevas

May 2019

IMF Working Papers describe research in progress by the author(s) and are published to elicit comments and to encourage debate. The views expressed in IMF Working Papers are those of the author(s) and do not necessarily represent the views of the IMF, its Executive Board, or IMF management.

\begin{abstract}
This paper analyzes the capital structure of private asset managers in which the acquisition of nonperforming loans (NPLs) is funded with Contingent Convertibles (CoCos) placed with investors. The paper develops a model based on NPL transfer prices and residual recovery rates to assess capital structures consisting of CoCos and equity. The CoCos would contain put and call options to write down losses and write up profits, respectively, arising from liquidation and restructuring procedures. The paper concludes that the protection mechanism provided by debt write-downs embedded in CoCos and the incentives to investors provided by debt write-ups could help bridge the gap between Portuguese banks' NPL bid prices and private equity firms' ask prices.
\end{abstract}

JEL Classification Numbers: G13, G32, G33

Keywords: Asset managers, contingent convertibles, asset pricing, nonperforming loans Author's E-Mail Address: asantos2@imf.org

\footnotetext{
${ }^{1}$ The author is grateful to seminar participants in Banco de Portugal, I. Agur, T. Bayle, J. Christopher, A. Cuevas, I. Drummond, A. R. Gonçalves, R. Goyal, P. Jeasakul, S. Lall, N. P. Novikova, M. Patnam, M. D. Piñeiro, M. Pradhan, J. Salas, A. Shabunina, and H. Vale for useful comments and suggestions.
} 


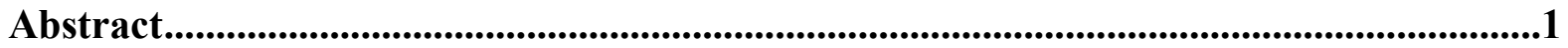

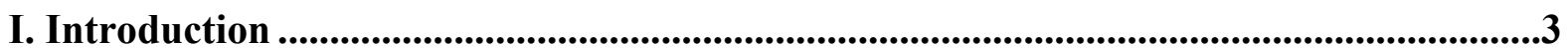

II. The Market for NPLs in Portugal .........................................................................5

III. The Use of Contingent Convertibles..........................................................................................10

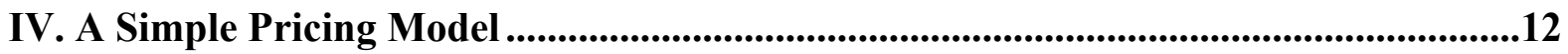

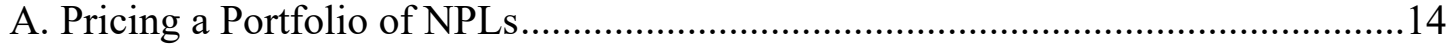

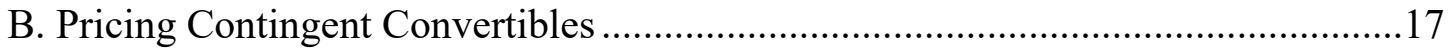

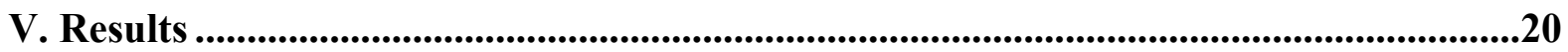

VI. Concluding Remarks ....................................................................................................22

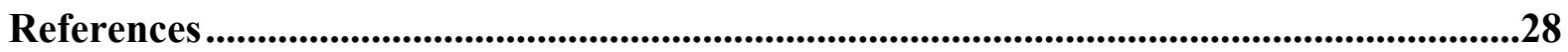

Tables:

1. Recent Transactions in the Portuguese and Italian Distressed Debt Markets......................8

2. Historical Recovery Rates for some NPLs in Italian Banks ......................................... 10

3. Impact of Debt Write-downs and Debt Write-ups on Private Asset Managers ..................24

4. Impact of Improvements in the Net Recovery Rate under Liquidation Procedures on

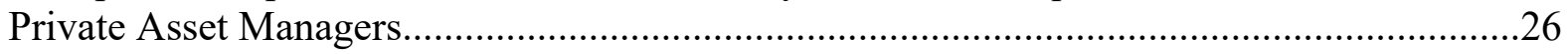

\section{Figures:}

1. Sales of NPLs in Portugal, Greece, Italy, Spain, and Ireland ..........................................5

2. Common Equity Tier 1 Capital and Coverage Ratios .................................................6

3. Sale Prices in the Italian Distressed Debt Market............................................................ 7

4. Simplified Transactions in Private Asset Management Companies ..................................14

5. Pricing NPLs and Any Related Security with a Binomial Tree.......................................18

6. Gross Loans Under Liquidation or Restructuring till Maturity Date................................22

\section{Boxes:}

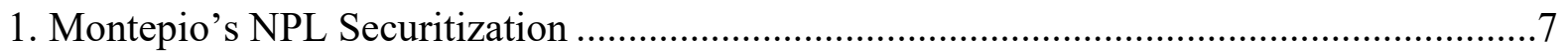

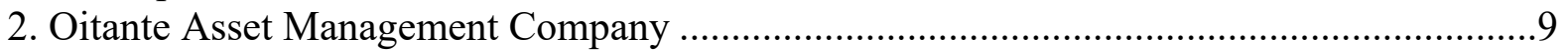

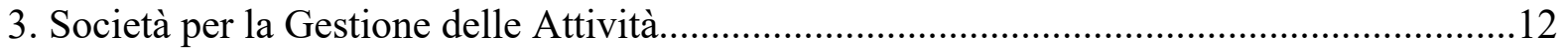




\section{INTRODUCTION}

Legacy assets have hampered the financial performance of Portuguese banks. The global financial crisis and the related euro area crisis have taken a toll on Portuguese banks. High levels of non-performing loans (NPLs) have put pressure on asset quality, profitability, and capital. They have also impaired the flow of credit to growing economies, contributing to a low level of investment. With public sector involvement constrained by state-aid rules and the lack of fiscal space, private capital has played a larger role in dealing with the legacy assets in Portugal. Since the 2016-17 capital injections, Portuguese banks have reduced their stock of NPLs and increased their provision coverage.

\section{Developing a market for NPLs is often key to promote the clean-up of banks' balance} sheets. Private equity firms are active in the market for NPLs, but they require a large return on investments and a deep discount on NPLs to invest in risky assets. More conservative provisioning policies would reduce the gap between banks' bid prices and private equity firms' ask prices. High capital ratios would also allow banks to write down NPLs, facilitating their sale at higher haircuts. However, given the low profitability and capital ratios in some Portuguese banks, sale to distressed debt investors at high haircuts is not a practical solution for all banks. Any proposal for the creation of a publicly-sponsored asset management company would need to consider existing regulatory, accounting, and legal frameworks (CRR, state-aid, BRRD, IFRS, restructuring, insolvency and collateral enforcement) and involve significant financial resources. Finally, initiatives relying on NPL securitization with government guarantees or on private-based funds such as Atlante, have thus far lacked the firepower for a comprehensive balance sheet clean-up.

This paper analyzes the capital structure of private asset managers (AMs) in which the acquisition of NPLs are funded with Contingent Convertibles (CoCos) placed with investors. ${ }^{2}$ CoCos issued by private AMs would not only protect private AMs by inflicting losses on investors arising from liquidation and restructuring procedures but would also allow investors to benefit from their profits. The paper initially reviews recent experiences of NPL sales in Europe and, in particular, in Portugal. The paper then develops a model based on NPLs sale prices and residual recovery rates to assess capital structures in private AMs consisting of equity and CoCos. The latter would contain put and call options to write down losses and write up profits, respectively, arising from liquidation and restructuring procedures. Finally, the paper concludes that the protection mechanism provided by debt write-downs embedded in CoCos and the incentives to investors provided by debt writeups could help bridging the gap between Portuguese banks' NPL bid prices and private equity firms' ask prices, increasing not only the number of transactions but also the transparency in the market. Portuguese banks would benefit from CoCos by reducing their

\footnotetext{
${ }^{2}$ Fixed income investors could also acquire the CoCos. The proceeds would then be used by asset managers to purchase NPLs from banks.
} 
NPL stock while private AMs would be able to expand their NPL purchases with debt, leveraging up their capital.

Overall, private AMs would acquire NPLs from financial institutions to benefit from liquidation and restructuring procedures while helping banks offload their NPLs and focus on new lending. Private equity firms such as Bain Capital, Anchorage, Arrow Global, AnaCap, and Balbec, could team up with Portuguese banks to form a joint venture (JV) with no control rights for the banks. ${ }^{3}$ Alternatively, either private equity firms could set up themselves a special vehicle purpose (SPV). ${ }^{4}$ Private equity firms and/or banks would then provide equity to establish the JV or the SPV, enabling the latter to issue CoCos to fund the NPL portfolio acquisition, restructure households and viable firms, and recycle productive assets. In particular, private AMs would add value to liquidation and restructuring procedures. For instance, recovery rates for unsecured consumer loans in debt collection and restructuring firms have outperformed European banks' recovery rates by 15-30 percentage points. ${ }^{5}$ In the corporate sector loan portfolio, private AMs would break banking relations, enabling them to maximize liquidation or restructuring recoveries in the case of non-viable firms. Finally, as in a NPL securitization that provides banks with higher transfer prices than an outright sale to private equity firms, banks would also benefit from a high demand for CoCos by investors with different risk-return profiles. ${ }^{6}$

The paper contributes to the literature on reducing the gap between bid and ask prices for NPL sales. It provides an alternative to the different mechanisms suggested in the literature. Fell, Moldovan, and O'Brien (2017) suggested two mechanisms in which the gap between bid and ask prices could be overcome. The first one is a guarantee on the equity tranche of NPL securitizations. The guarantee up to a maximum of 50 percent of the tranche would be offered by the state and would be structured as a total return swap, implying that the state would exposed to the same risk-return profile in tranche as investors. The price paid for NPLs would increase indirectly because of the interest by the state to improve residual recovery rates and mitigate losses. The second mechanism is a forward purchase scheme in which the state funds partially the purchase price paid by the investor to the banks. The financed part is related to the difference between the price the investor is willing to pay at the maturity and the price paid at the inception. The forward purchase scheme would include a

\footnotetext{
${ }^{3}$ Deloitte (2017) contains detailed information on NPL sales across Portugal and Europe.

${ }^{4}$ One example is the sale and transfer of NPLs by Catalunya Bank to a SPV in 2014 in which Blackstone held majority interest and all the senior bonds while the Spanish Executive Resolution Authority (FROB) retained the junior/subordinated bonds. Another example is UniCredit' agreement with Fortress and PIMCO announced on December 13, 2016 to transfer two NPL portfolios to independent entities in which it would retain a minority position.

${ }^{5}$ See Hoist Finance (2016).

${ }^{6}$ However, securitizations are riskier, costly, and time consuming. Carlisle and Poilpre (2017) indicated that investors can obtain a 12-20 percent return on an outright sale while a lower 10-12 percent return on a securitization.
} 
guarantee to mitigate the credit risk incurred by the state and its financing would be based on the funding costs associated with the guarantor. Finally, the investor would pay a higher price for the NPLs as the financing provided by the state would be lower than his internal rate of return and its repayment could be done from the NPL recovery proceeds.

NPL sales to private AMs would provide banks with some capital relief from the deconsolidation of transferred NPLs. On the transfer date, banks would recognize losses if transfer prices are below booked values (net of provisions). NPLs transferred to private AMs would then not be consolidated in banks' balance sheets so long as IFRS10 rules are met. To this end, banks could have rights to variable returns from their involvement with private AMs, but their rights would not be intended to provide them with neither any power over private AMs nor with any ability to use their power to affect private AMs' returns - that is, write-ups would not be matched by control rights. ${ }^{7}$ This could hopefully provide Portuguese banks with some capital relief as long as CoCos are not held by the originating banks, in which case the deconsolidation could be in question.

\section{The Market for NPLs in Portugal}

In Portugal NPL sales jumped in 2018. Figure 1 indicates that NPL sales in Portugal amounted to $€ 1.6$ billion in 2015 , $€ 2.3$ billion in 2016 and 2017, and $€ 7.4$ billion (including ongoing sales) in 2018, representing an average of 10 percent of total NPLs over the period. ${ }^{8}$ In contrast, average NPL sales in Italy, Spain, and Ireland have been higher at about $€ 37.7$ billion, $€ 29.6$ billion, and $€ 16.6$ billion per year over the period $2014-18$, respectively. They have also represented an average of 13.1 percent, 20.9 percent, and 29.0 percent of NPLs, respectively, over the period. Deloitte (2017) estimates that most NPL sales in Portugal have been concentrated in the consumer loan market segment during 2015-17, while NPL sales have consisted of mixed asset classes in Italy and Spain and of residential real estate in Ireland.

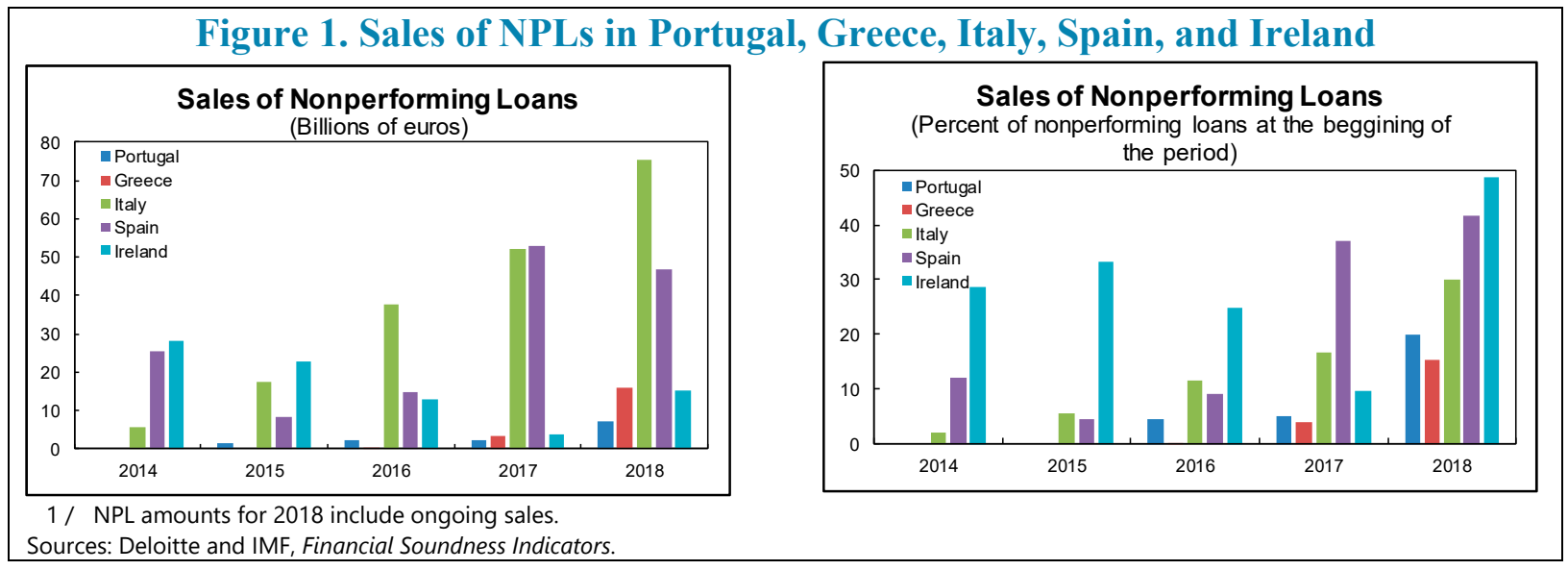

\footnotetext{
${ }^{7}$ This disqualifies any balance sheet consolidation under IFRS10 as banks would have no control over the private AM.

${ }^{8}$ See Deloitte (2017).
} 
Differences in types of NPLs and coverage ratios can help explain the low level of NPL sales in Portugal over the last few years. The different pace of sales in Ireland, Spain, Italy, and Portugal can be partially traced back to the earlier impact of the European crisis on Irish and Spanish banks and to the type of NPLs, with household loans being a significant part of NPLs in Irish and Spanish banks while loans to nonfinancial corporations represented a substantial part of NPLs in Italian and Portuguese banks. Moreover, the public asset management companies created in Ireland and Spain in 2009 and 2012, respectively, also helped jumpstart the secondary market for NPLs. Finally, high coverage ratios in Italian and Spanish banks have facilitated the reduction of the gap between bid and ask prices by private AMs and banks while the and high capital ratios in Irish banks have helped absorb losses from NPL sales.

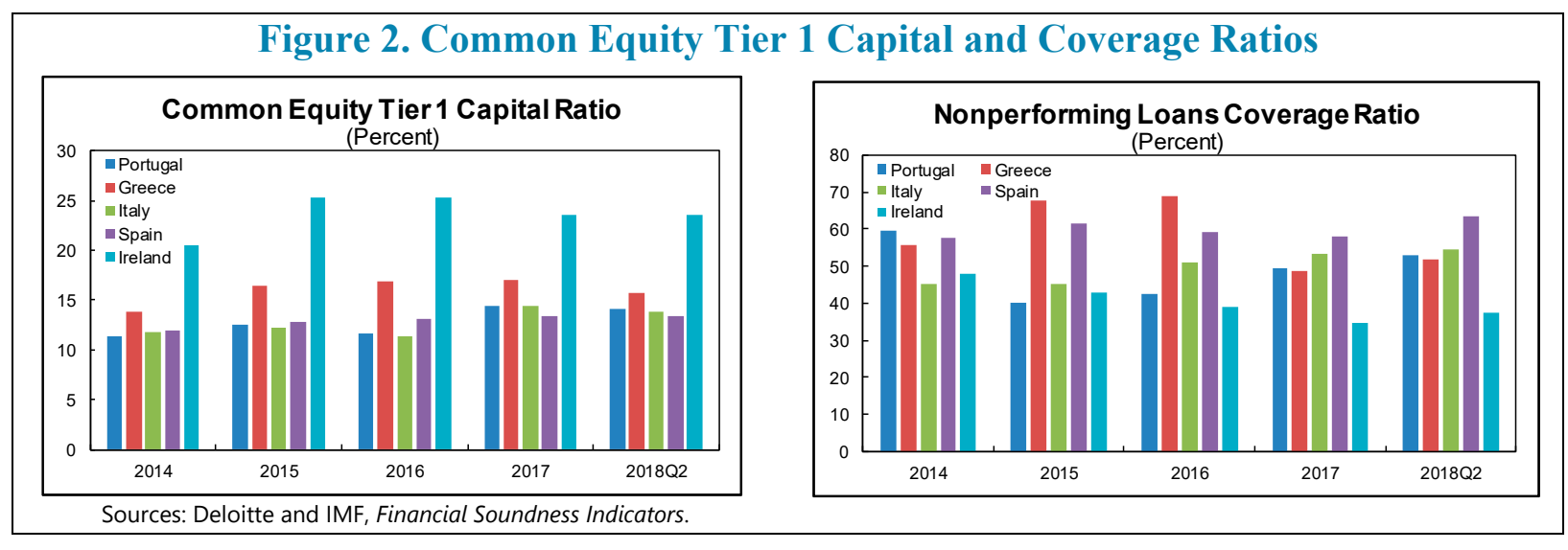

The latest NPL transactions in the Portuguese distressed debt markets suggest that higher capital and coverage ratios in Portuguese banks will further encourage larger NPL sales. Overall, capital buffers and provisions in Portuguese banks have improved since 2016 and are comparable to other Italian and Spanish banks at end-June 2018 according to Figure 2. Table 1, panel A presents some recent NPL sale transactions in Portugal. They include CDG's disposal of $€ 476$ million in secured NPLs to Bain Capital in July 2017 at an undisclosed price following the conclusion of a $€ 5$ billion recapitalization plan at end-March 2017 and Montepio's $€ 580$ million in secured and unsecured loans to Hefesto, STC in November 2017 at 30.4 percent of the gross book value (GBV) — as described in detail in Box 2-after a $€ 250$ million capital increase in June 2017. The latter transaction is consistent with the 33-40 percent price range for secured loans in the Italian distressed debt market but is higher than the 3-8 percent price range for unsecured loans as shown in Table 1, panel B and Figure 3. For instance, Unicredit sold a portfolio of unsecured NPLs at 13 percent of GBV in July 2017. However, with more distressed loan portfolio and under extreme circumstances, NPL transfer prices can be lower. In the state intervention in Portugal to resolve Banco Internacional do Funchal (Banif) at end-2015, Oitante acquired Banif's loan portfolio for 12 percent of GBV as detailed in Box 3. 


\section{Box 1. Montepio's NPL Securitization}

Montepio successfully securitized a portfolio of NPLs following a capital increase in June 2017. The $€ 250$ million capital increase and a reduction in risk weighted assets helped it to raise its common equity Tier 1 capital ratio from 10.2 percent in March 2017 to 13 percent in September 2017. With higher capital ratios, Montepio securitized $€ 580.6$ million of NPLs in November 2017. The transaction involved Hefesto STC acquiring the NPL portfolio and publicly offering $€ 176.3$ million (transfer price at 30.4 percent of GBV) in senior, mezzanine, and junior notes without a recourse or a guarantee from the Portuguese government. The notes were collateralized by 20,000 nonperforming secured ( 46.7 percent of GBV, consisting of residential and commercial loans) and unsecured (53.3 percent) loans, with an average outstanding value of $€ 28,000$ thousand. Moody's and DBRS assigned investment grade rating to the senior tranche, which represents about 71.5 percent of the NPLs' GBV.

The transfer price reflected expected gross recovery rates for secured loans. Loan servicers projected an average 36.7 percent gross recovery rate under judicial proceedings, with a high 71.6 percent gross recovery rate for secured loans and a low 6.2 percent rate for unsecured loans under the baseline. In its rating analysis, DBRS stressed the projected cash recoveries by applying a 23.6 percent haircut to the gross collections. The stressed average gross recovery rate declined to 28 percent, or 8.7 percentage points lower than the loan servicers'

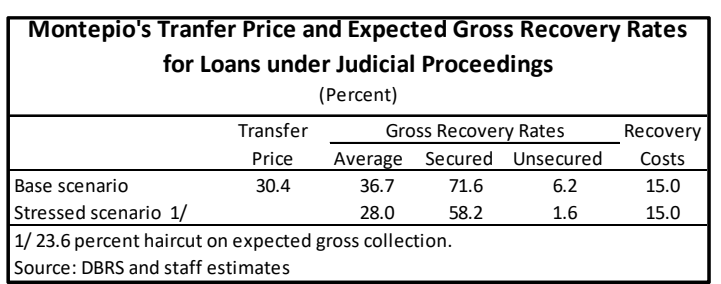

Source: DBRS and staff estimates projection. DBRS additionally assumed that recovery costs represented 15 percent of GBV. Finally, the average of loan servicers' track record in resolving secured loans amicably was 58 percent while the only track record for unsecured loans was 42 percent.

Figure 3. Sale Prices in the Italian Distressed Debt Market

(Percent of banks' gross book value; weighted average by book value)

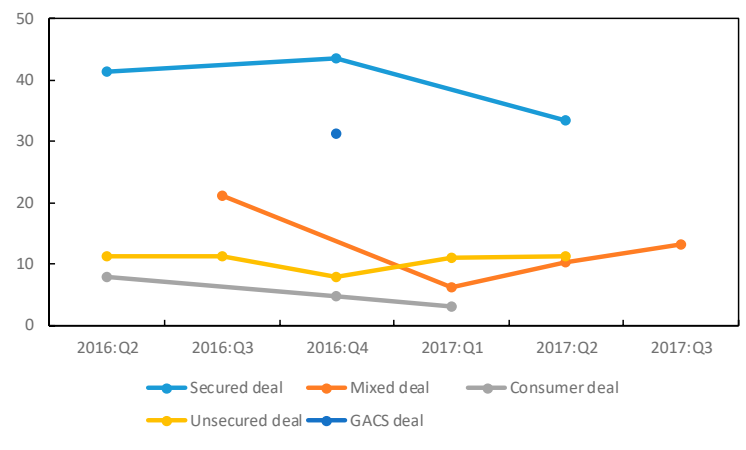

Sources: Banca IFIS (2017), Market Watch NPLs, July 2017. 
Table 1. Recent Transactions in the Portuguese and Italian Distressed Debt Markets

A. Portuguese market

\begin{tabular}{lcccl}
\hline Institution & $\begin{array}{c}\text { Gross Book } \\
\text { Value (Millions } \\
\text { of euros) }\end{array}$ & $\begin{array}{c}\text { Sale Price } \\
\text { (Percent of } \\
\text { gross book } \\
\text { value) }\end{array}$ & Annoucenment Date & Portfolio \\
\hline BANIF 1/ & 1,261 & 12.4 & Dec-15 & Secured and unsecured loans \\
CDG & 476 & NA & Jul-17 & Secured loans to SMES and large corporates \\
Oitante & 1,500 & NA & Apr-17 & NPLS and REOs \\
CDG, BCP & NA & NA & Sep-17 & Corporate loans \\
CEMG & 580.6 & 30.4 & Nov-17 & Secured and unsecured loans \\
CDG & 350 & NA & Dec-07 & Residential and REOs \\
BCP & 500 & NA & Dec-17 & Corporate loans \\
CDG & 1,200 & NA & 2018 & NA \\
Novo Banco & 2,000 & NA & 2018 & NA \\
Montepio & 239 & NA & 2018 & NA \\
Santander & 1,000 & NA & 2018 & NA \\
BCP & 730 & NA & 2018 & NA \\
\hline
\end{tabular}

B. Italian market

\begin{tabular}{lcccl}
\hline Institution & $\begin{array}{c}\text { Gross Book } \\
\text { Value (Millions } \\
\text { of euros) }\end{array}$ & $\begin{array}{c}\text { Sale Price } \\
\text { (Percent of } \\
\text { gross book } \\
\text { value) }\end{array}$ & Annoucenment Date Portfolio & \\
\hline Banca UBI & 82 & 5.5 & Jan-16 & Unsecured loans \\
Credito Valtellinese & 106 & 41.0 & $5 / 27 / 2016$ & Secured loans \\
Credito Valtellinese & 22 & 35.0 & $6 / 8 / 2016$ & Secured loans \\
Monte dei Paschi di Siena & 350 & 14.6 & $6 / 23 / 2016$ & Unsecured loans \\
UniCredit 2/ & 940 & 1.8 & $10 / 19 / 2016$ & Unsecured loans \\
Credito Valtellinese & 105 & 43.0 & $12 / 19 / 2016$ & Secured loans \\
Banca IFIS 2/ & 744 & 5.6 & $12 / 22 / 2016$ & Unsecured loans \\
Credito Valtellinese & 50 & 44.0 & $3 / 27 / 2017$ & Secured loans \\
Banco BPM 3/ & 693 & 35.0 & $6 / 13 / 2017$ & Secured loans \\
Monte dei Paschi di Siena & 26,190 & 21.0 & $7 / 5 / 2017$ & Unsecured loans \\
Credito Valtellinese 4/ & 1,400 & 37.5 & $7 / 13 / 2017$ & NA \\
UniCredit 5/ & 17,700 & 13.0 & $7 / 17 / 2017$ & Unsecured loans \\
Credito Valtellinese & 24 & 58.0 & $12 / 5 / 2017$ & Secured loans \\
Monte dei Paschi di Siena & 24,100 & 17.8 & $5 / 10 / 2018$ & NA \\
\hline
\end{tabular}

Source:Bain Capital, Moody's, DBRS, and Deloitte, bank press releases, Jounral dos Negocios (2019), and Kruk's 2016 annual report.

1/ Transfer price estimated from Oitante's balance sheet at end-2015.

2/ Author's estimate.

3/ Sale price reported in Bloomberg news on June 9, 2017.

4/ Sale price reported in Banca IFIS (2017).

5/ Sale price reporte in Bank of Italy (2017). 


\section{However, the disclosure of sale prices and gross recovery rates is low in Portuguese distressed debt markets, detering investors and hindering price formation. Some banks} such as Banco Comercial Português and Santader Totta have been selling NPLs on the market for years as part of their risk management. However, not much information about their transactions is publicly available. On the other hand, some Italian banks have been forthcoming about disclosures of sale prices and gross recovery rates. Table 2 shows estimated recovery rates for NPLs in Italian banks, as reported by the Bank of Italy. It indicates that, overall, recovery rates declined over the last few years, reflecting a deterioration in asset quality. In addition, banks sold their worst loan portfolios to distressed-debt investors as suggested by the average 23 percent recovery rate over the period 2006-16 - against a 47 percent recovery rate for NPLs retained by banks. As expected, recovery rates for NPLs secured by collateral were higher than for unsecured ones while recovery rates for nonperforming retail loans were higher than for nonperforming corporate loans, although the gap has been declining over the last few years. In the case of Montepio's NPL transfer to Hefesto, DBRS' stressed projected gross recovery rates are more in line with Italian historical gross recovery rates than loan servicers' projections. In particular, the distressed projected gross recovery rate for secured loans is closer to the Italian ones than for the unsecured ones.

\section{Box 2. Oitante Asset Management Company}

Oitante acquired NPLs from the state intervention to resolve Banco Internacional do Funchal (Banif) at end-December 2015. The resolution of Banif led to the transfer of most of its assets and liabilities to Santander Totta. ${ }^{1}$ The Portuguese state and the Resolution Fund jointly injected $€ 2.255$ billion to recapitalize Banif and sell it to Santander Totta for a total of $€ 150$ million. The remaining assets with a book value of $€ 2.2$ billion were transferred from Banif to Oitante - which is owned by the Resolution Fund - at a price of $€ 787.9$ million, implying an average haircut of 75 percent. Oitante also issued $€ 746$ million in bonds guaranteed by the Resolution Fund and counter-guaranteed by the Treasury to Santander Totta. The transferred assets to Oitante consisted of secured and unsecured customer loans, financial participations, and real estate, including Banif's related-party exposures. ${ }^{2}$

Since the asset transfer, Oitante has strived to sell Banif's assets and generate cash. It has sold Banif's insurance, securitization, and pension fund companies, its investment bank, and its Malta subsidiary. ${ }^{2}$ The sale of Oitante's servicing platform to Altamira Asset Management and the associated servicing and management agreement of NPLs and real estate assets (amounting to $€ 1.5$ billion) should improve recovery rates and loan prices. In particular, loans to customers were priced at 12.4 percent of GBV on the balance sheet at end-2015 while the expected recovery rate associated with restructured loans amounted to 21.8 of GBV, with the estimated recovery rate for restructured secured and

\begin{tabular}{|c|c|c|c|c|}
\hline \multicolumn{5}{|c|}{$\begin{array}{c}\text { Oitante's Prices and Expected Recovery Rates for } \\
\text { Restructured Loans } \\
\text { (Percent of gross book value) }\end{array}$} \\
\hline & \multirow[t]{2}{*}{ Transfer Price } & \multicolumn{3}{|c|}{ Gross Recovery Rates } \\
\hline & & Average & Secured & Unsecured \\
\hline Oitante & 12.4 & 21.9 & 59.5 & 6.8 \\
\hline
\end{tabular}
unsecured loans estimated at 47.3 percent and 11.7 percent, respectively. ${ }^{3}$

${ }^{1}$ See International Monetary Fund (2016) for a summary of the transactions.

${ }^{2}$ See Oitante's web page.

${ }^{3}$ See Oitante (2017). 


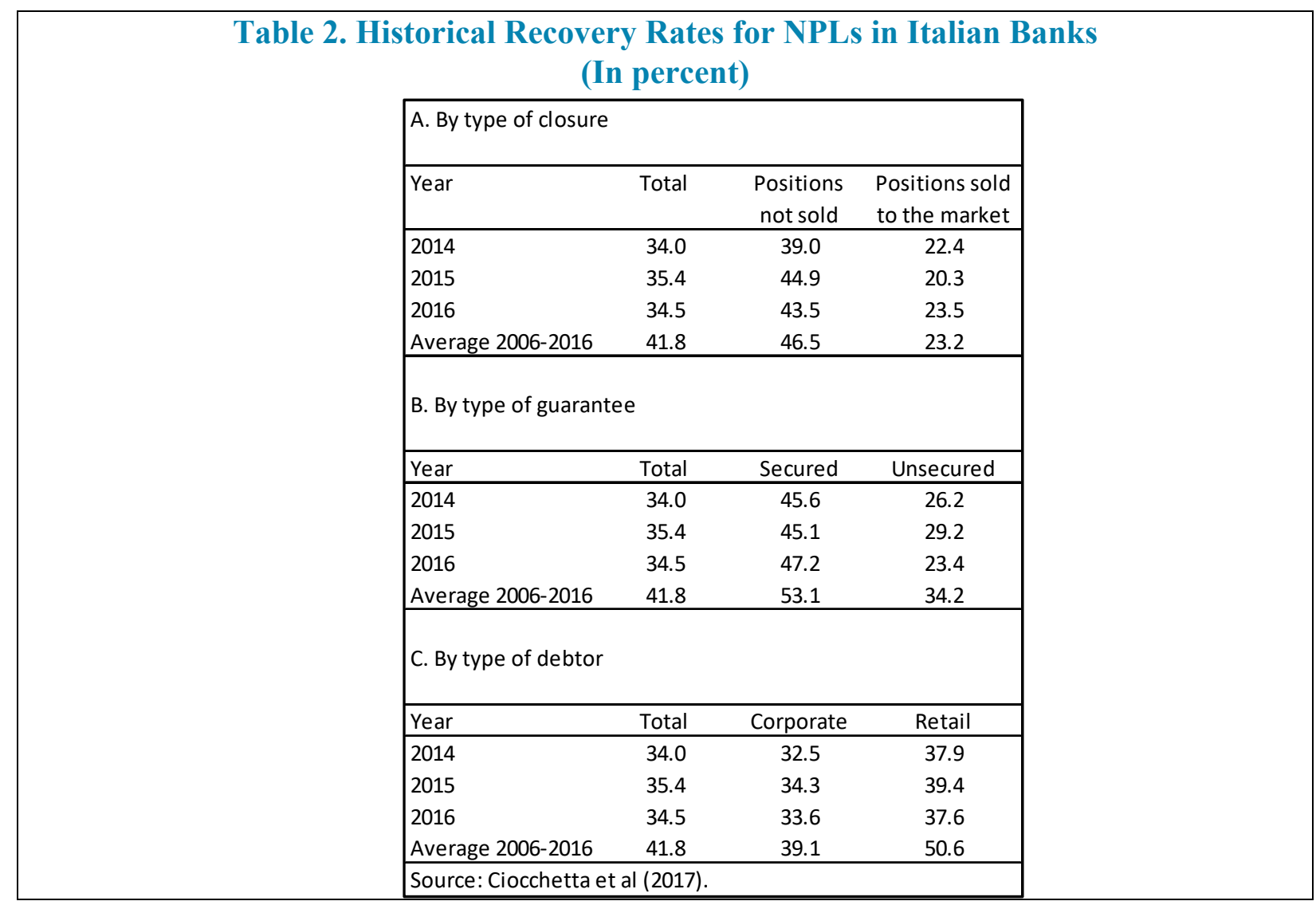

\section{The USE OF CONTINGent Convertibles}

The issuance of the standard CoCos has helped banks manage their capital ratios. CoCos may help improve financial stability and prevent large-scale public interventions at the cost of the taxpayer by inflicting losses on bondholders from debt-equity conversions or debt write-downs in a bank with low capital levels. According to a Fitch compendium (last update on June 30,2017), CoCos have been issued by about 150 banks from both emerging markets and advanced economies. The majority of CoCos have been made up of Additional Tier 1 (AT1) instruments with 283 issuances amounting to $\$ 274.5$ billion while Tier 2 instruments have consisted of 21 issuances amounting to $\$ 22.5$ billion. AT1 instruments are mostly deeply subordinated as they are perpetual securities. Most AT1 and T2 instruments have a principal write-down mechanism, with only a few instruments containing a debtequity conversion. Even though most instruments allow for a full principal write-down, this is not on a permanent basis as some instruments allow for principal write-ups. The conversion or write-down triggers for both AT1 and T2 instruments range from 5 percent to 8 percent of common equity Tier 1 (CET1) capital.

References to CoCos associated with NPL transfers and losses have been made in the context of discussions on publicly-sponsored asset management companies. Box 3 summarizes the experience with a debt reduction mechanism associated with the conversion of losses from liquidation and restructuring procedures in the Società per la Gestione delle 
Attività (SGA, Italy). This provides useful insights on how a CoCo with debt conversion features would work. Enria, Haben, and Quagliariello (2017) proposed a pan-European asset management company with a capital structure consisting of equity and straight coupon bonds but added an ex-post loss claw-back mechanism to protect it against losses. ${ }^{9}$ The possible capital gap in the banks would then be covered by equity warrants placed with governments concomitantly with NPL transfers. They also suggested alternative approaches such as an exchange of bonds (or tranches of securitized instruments) for NPLs and CoCo issuance. Avgouleas and Goodhart (2017) also favored profit and loss agreements with banks. These would contain claw-back clauses to discourage moral hazard by requiring banks to make further payments if losses emanating from their loans portfolios were higher than the average. The compliance of CoCos with BRRD, IFRS, and State-aid rules in all the proposals above would need to consider not only the relation between NPL transfer prices and their real economic value (REV) but also the protection mechanism provided by debt write-downs and the incentives provided by debt write-ups. This would require assessments on a case-by-case basis, considering transfer prices, REVs, recovery rates under different scenarios, put and call options, coupon rates, any additional equity provided to offset expected losses, and reinvestment rates.

\footnotetext{
${ }^{9}$ NPLs would be transferred at NPLs' real economic value and shareholders and junior debt holders would contribute to burden-sharing. The implicit state-aid would be equivalent to the difference between NPLs' market price and their real economic value determined under an adverse stress test scenario. However, banks would still have their capital ratios affected by the difference between the higher booked value and the lower real economic value. This ex-ante difference could be covered by a shareholder capitalization or a junior debtequity conversion.
} 


\section{Box 3. Società per la Gestione delle Attività}

The Società per la Gestione delle Attività (SGA, Italy) was established in 1996 as hive-off vehicle to help in the sale of Banco di Napoli. The underlying cash flows associated with SGA illustrate the conversion of losses in liquidation and restructuring procedures. The stock of debt issued by SGA to Banco di Napoli was reduced in tandem not only with incurred losses but also with net cash recoveries. SGA's net losses peaked in 1999 but a period of net cash recoveries after 2003 benefited from positive macroeconomic conditions before the financial crisis. As a result, over more than 10 years were needed to achieve a substantial reduction in NPLs in SGA's balance sheet. However, Banco di Napoli did not benefit directly from the higher recoveries as it did not acquire an equity participation in SGA in the initial capitalization or from the debt reductions. The high recovery rates allowed prepayments before the maturity date while Banco di Napoli was safeguarded against losses in SGA by the debt reduction associated with the net proceeds from higher interest rate earned on Italian government bonds than paid on the Bank of Italy's advances. ${ }^{1}$ The final recovery rate was 65 percent of gross book value (or 92 percent on the net book value). ${ }^{2}$

${ }^{1}$ This funding mechanism has a monetary impact.

\begin{tabular}{|rrrrr|}
\hline & $\begin{array}{c}\text { Net loans } \\
\text { (EUR } \\
\text { million) }\end{array}$ & $\begin{array}{c}\text { Debt } \\
\text { (EUR } \\
\text { million) }\end{array}$ & $\begin{array}{c}\text { Debt } \\
\text { Reduction } \\
\text { (EUR } \\
\text { million) }\end{array}$ & $\begin{array}{r}\text { Losses and } \\
\text { Recoveries } \\
\text { (Accrual } \\
\text { basis, EUR } \\
\text { million) }\end{array}$ \\
\hline 1996 & 6,428 & 6,428 & & \\
1997 & 5,683 & 5,665 & -763 & -633 \\
1998 & 4,650 & 4,994 & -672 & -766 \\
1999 & 4,014 & 3,815 & $-1,179$ & -945 \\
2000 & 2,909 & 2,773 & $-1,042$ & -561 \\
2001 & 2,325 & 2,069 & -704 & -525 \\
2002 & 1,742 & 1,299 & -770 & -283 \\
2003 & 1,701 & 1,052 & -247 & 0 \\
2004 & 1,375 & 805 & -247 & 12 \\
2005 & 1,186 & 654 & -151 & 15 \\
2006 & 790 & 462 & -192 & 22 \\
2007 & 656 & 222 & -240 & 61 \\
2008 & 551 & 64 & -158 & 34 \\
2009 & 508 & 0 & -64 & 23 \\
2010 & 421 & & & 49 \\
2011 & 367 & & & 113 \\
2012 & NA & & & -2 \\
2013 & NA & & & 14 \\
2014 & NA & & & 13 \\
2015 & NA & & & 30 \\
\hline Source: Banca d'Italia annual reports, Sao Paolo annual \\
reports, European Commission (1999), and Maglio \\
(2016). \\
\hline
\end{tabular}

${ }^{2}$ Erzegovesi (2017).

\section{A Simple Pricing Model}

From a pricing perspective, the unconventional CoCos proposed in this paper are also a combination of debt and equity instruments. Asset managers would acquire banks' NPLs with funding provided by the unconventional CoCos placed with investors. The standard CoCos are priced using either the credit or the equity derivatives approaches. ${ }^{10}$ The reducedform credit derivatives approach considers CoCos as defaultable bonds with cash as the final payoff and matches the dynamics of credit derivatives prices with a random process. The equity derivatives approach uses an equity derivatives portfolio consisting of a knock-inforward and a bond that replicates the final payoff (shares of equity). The approach taken in the paper to the price the unconventional CoCos issued by private AMs is similar to the CDO methodology in O'Kane (2011), except that it considers only one debt instrument, a NPL portfolio with single names, and different recovery rates. Moreover, the seniority of the securities is partially or fully reversed, with CoCos initially bearing losses from low cash recoveries. ${ }^{11}$

This paper assumes that NPLs can be priced out of "recoveries." In finance, most credit risk models are based on default as a possible event with an associated probability of default

\footnotetext{
${ }^{10}$ For a summary of the different approaches, see Jung (2012) and Pennachi and Tchisty (2018).

11 The unconventional CoCos would also be similar to Credit Linked Notes where the underlying is not a CDS written on a reference entity but a NPL portfolio.
} 
(PD) and a recovery rate (RR) given default. In the case of NPLs, default has already taken place and investors' and banks' focus is on possible recoveries from liquidation and restructuring procedures. Key assumptions in this paper are that: (i) NPLs have different recovery rates in liquidation and restructuring procedures; and (ii) each procedure is associated with a different probability of occurrence. This is consistent with Antunes and Ribeiro (2004) who analyzed recovery rates for NPLs under liquidation and recovery scenarios in Portugal, and with Peter (2011) who suggested that loss given default reflects a mixture probability distribution for after-default scenarios. ${ }^{12}$ Schuermann (2004) also indicated that evidence from bonds markets suggests bimodal probability distribution for recovery rates.

Simple accounting transactions underlie the pricing framework. Private AMs are initially funded not only with equity to provide them with liquidity and cover unexpected losses but mostly with CoCos placed with investors to acquire NPLs from banks. Instead of a debtequity combination, private AMs could also be fully funded with equity raised from private equity firms or banks. Figure 4 illustrates the underlying accounting transactions. Private AMs obtain cash recoveries from liquidation and restructuring procedures in tandem with a simultaneous reduction in the stock of NPLs booked at transfer prices. They benefit (incur losses) from NPL transfers when recovery rates are higher (lower) than transfer prices. The difference between cash recoveries and transfer prices is then booked as a profit (loss) in equity.

\footnotetext{
${ }^{12}$ Krebel (2010) used a distribution of recovery rates to price distressed CDOs.
} 


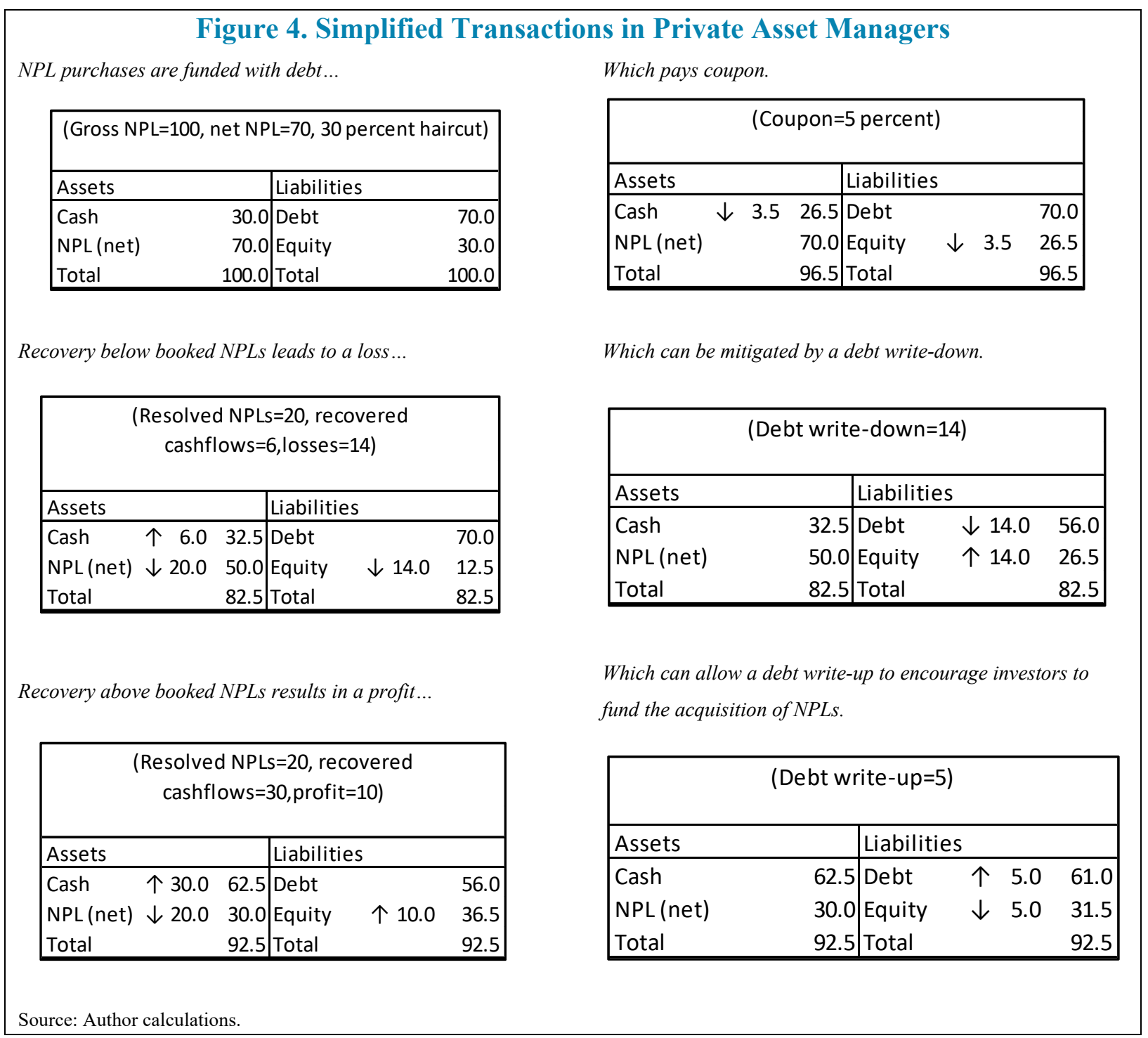

\section{A. Pricing a Portfolio of NPLs}

To assess the capital structure of private AMs containing CoCos that are exchanged for Portuguese banks' NPLs, a model to price a portfolio of NPLs is needed. The model assumes that the NPL portfolio is partitioned into $T$ sets containing loans to be partially restructured or liquidated at times $1, \ldots, t, \ldots, T$, with each set at time $t$ containing $N_{t}$ loans $l_{1, t, \ldots,} l_{i, t, \ldots,} l_{N t, t}$ amounting to:

$$
L_{t}=\sum_{i=1}^{N_{t}} l_{i, t},
$$

where, for simplicity, each obligor $i$ has only one loan granted $l_{i, t}$ to be liquidated or restructured at time $t$ and no other loans at any time. The residual recovery rate $R R$ i (gross 
cash recovery net of recovery costs) for obligor $i$ as a percentage of the loan $l_{i, t}$ granted to obligor $i$ is assumed to be an independent scaled Bernoulli random variable: ${ }^{13}$

$$
R R_{i}=\left\{\begin{array}{c}
R R_{1} \text { with } \text { probability } p_{1} \\
R R_{2} \text { with probability } 1-p_{1}
\end{array},\right.
$$

where $R R_{1}$ is lower than $R R_{2}$ and $p_{1}$ is the probability of each loan $l_{i, t}$ being liquidated between $t-1$ and $t$. For simplicity, the residual recovery rates $R R 1$ and $R R 2$ and the probability $p_{1}$ are assumed to be the same for all obligors at all periods of time. ${ }^{14}$

Given the assumptions above, the residual recovery rate $R R_{t}$ for the set of loans $l_{1, t}, \ldots$, $l_{i, t}, \ldots, l_{N t, t}$ is a weighted average of Bernoulli random variables. The possible outcomes for the random residual recovery rate $R R_{\mathrm{t}}$ are:

$$
R R_{t}=\left\{\begin{array}{c}
w_{1} R R_{1}+w_{2} R R_{1}+\ldots+w_{i} R R_{1}+\ldots+w_{N_{t-1}} R R_{1}+w_{N_{t}} R R_{1} \\
\ldots \\
w_{1} R R_{1}+w_{2} R R_{1}+\ldots+w_{i} R R_{2}+\ldots+w_{N_{t-1}} R R_{2}+w_{N_{t}} R R_{2}, \\
\ldots \\
w_{1} R R_{2}+w_{2} R R_{2}+\ldots+w_{i} R R_{2}+\ldots+w_{N_{t-1}} R R_{2}+w_{N_{t}} R R_{2}
\end{array}\right.
$$

where there are $2^{N t}$ permutations of recovery rates $R R 1$ and $R R_{2}$, and where the weights $w_{1, t}, \ldots w_{i, t}, \ldots, w_{N t, t}$ are given by:

$$
w_{i, t}=\frac{l_{i, t}}{L_{t}} .
$$

The $2^{N t}$-by-one vector of probabilities $p_{t}$ for the random residual recovery rate $R R_{t}$ is given

by:

$$
p_{t}=\left\{\begin{array}{c}
p_{1}^{N_{t}} \\
\cdots \\
p_{1}^{N_{t}-i}\left(1-p_{1}\right)^{i} \\
\cdots \\
\left(1-p_{1}\right)^{N_{t}}
\end{array}\right.
$$

\footnotetext{
13 The mean of the independent scaled Bernoulli distribution is given by $p_{1 t} R R_{1}+\left(1-p_{1 t}\right) R R_{2}$ while its variance is given by $p_{1}\left(R R_{1}-p_{1} R R_{1}-\left(1-p_{1}\right) R R_{2}\right)^{2}+\left(1-p_{1}\right)\left(R R_{2}-p_{1} R R_{1}-\left(1-p_{1}\right) R R_{2}\right)^{2}$.

14 The probability $p_{1}$ can be interpreted as an average probability across all obligors. It can also be time dependent to accommodate differences in expectation related to recoveries. For instance, as the economy recovers from a recession, the probability of liquidation could decline. In this case, the probability $p_{1}$ can be written as a function of time $t$ as in $p_{1, t}=\exp (\alpha t)$.
} 
In the case of homogeneous portfolios, the expressions above can be simplified. If all NPLs in the portfolio are approximately of the same size $l$, the residual recovery rate $R R_{t}$ is a binomial random variable with possible outcomes given by: ${ }^{15}$

with probabilities given by:

$$
R R_{t}=\left\{\begin{array}{c}
R R_{1} \\
\cdots \\
\frac{\left(N_{t}-i\right) R R_{1}+i R R_{2}}{N_{t}}, \\
\cdots \\
R R_{2}
\end{array}\right.
$$

$$
p_{t}=\left\{\begin{array}{c}
p_{1}^{N_{t}} \\
\cdots \\
\frac{N_{t} !}{i !\left(N_{t}-i\right) !} p_{1}^{\left(N_{t}-i\right)}\left(1-p_{1}\right)^{i} \\
\cdots \\
\left(1-p_{1}\right)^{N_{t}}
\end{array}\right.
$$

where there are $N_{t}+1$ number of combinations associated the residual recovery rate $R R_{\mathrm{t}}$ for the set of loans $l_{1, t}, \ldots, l_{i, t}, \ldots, l_{N t, t}$ to be restructured or liquidated at time $t$.

The model also assumes that NPL transfer or sale prices reflect expected discounted residual cash recoveries. NPL transfer prices are assumed to be the clearing prices with no risk and liquidity premia at which banks and the private AMs are willing to deal. ${ }^{16}$ As a result, the price $H_{0}$, as a percentage of total gross loans, paid for the loan portfolio would be equal to the expected discounted residual cash recoveries for all loans under liquidation or restructuring procedures throughout time $T$ :

$$
H_{0}=\frac{1}{\sum_{t=1}^{T} L_{t}} E_{0}^{Q}\left(\sum_{t=1}^{T} \frac{R R_{t} L_{t}}{\left(1+r_{0}\right)^{t}}\right),
$$

where $E_{0} Q$ is the expectation at time 0 under a risk neutral distribution of all cash recoveries throughout time $T$ and $r_{0}$ is the risk-free interest rate. This is a simplified version of the

\footnotetext{
15 To calculate the probabilities recursively, see O'Kane (2011).

${ }^{16}$ An externally determined liquidity premium could be added to account for the low liquidity in debt distressed markets.
} 
model to price distressed bonds in Guo, Jarrow, and Lin (2008) but in a context of NPL pricing. Given that $p_{1}, R R_{1}, R R_{2}, r_{0}, H_{0}$, and the total loan amounts $L_{1}, \ldots, L_{t}, \ldots, L_{T}$ to be restructured or liquidated are known, the probability $p_{1}$ can be found by numerically solving equation (8) for $p_{1}$. Figure 5, Panel A illustrates NPL pricing with a non-recombining binomial tree with three periods, one loan per period-loans $L_{1}$ and $L_{2}$ - to be restructured or liquidated, and residual recovery rate $R R_{1}$ and $R R_{2}$ associated with probabilities $p_{1}$ and 1- $p_{1}$, respectively. The price of the NPL portfolio would be no more than the expected discounted residual recovery rates weighted by their respective probabilities.

\section{B. Pricing Contingent Convertibles}

CoCos would provide private AMs with a mechanism to acquire NPLs and mitigate losses and share gains arising from liquidation and restructuring procedures with investors. Periodic debt write-downs would offer a protection to private AMs against transfer prices that do not reflect underlying residual recovery rates. The protection against losses would be equivalent to put options written on the random residual recovery rate $R R_{t}$ in which the payoff is given by: ${ }^{17}$

$$
\text { Write-off }=-\varphi \max \left(\left(H_{0}-R R_{t}\right) L_{t}, 0\right),
$$

where, if positive, the difference $\left(H_{0}-R R_{t}\right) L_{t}$ reflects the loss from liquidation or restructuring procedures, and $\varphi$ is the percentage of the losses that are written down. The put options can then be priced out of the probability distribution for the random residual recovery rate $R R_{\mathrm{t}}$. Their price at time 0 is the expected discounted cash flows at time $t$ :

$$
P u t_{0}=E_{0}^{Q}\left(-\frac{\varphi}{\left(1+r_{0}\right)^{t}} \max \left(\left(H_{0}-R R_{t}\right) L_{t}, 0\right)\right) \text {. }
$$

On the other hand, periodic debt write-ups would enable investors to benefit from high residual recovery rates. Periodic debt write-ups should be limited by the restriction that the debt stock $D_{t}$ at time $t$ after the debt write-up cannot be higher than the debt stock $D_{0}$ at time 0 . Thus, debt write-ups are capped power options written on the random residual recovery rate $R R_{\mathrm{t}}:{ }^{18}$

$$
\text { Write }- \text { up }=\lambda \min \left(\max \left(\left(R R_{t}-H_{0}\right) L_{t}, 0\right), D_{0}-D_{t-1}\right),
$$

\footnotetext{
${ }^{17}$ This is similar to Additional Tier 2 (AT2) capital with no debt-equity conversion, with the exception that the trigger is losses arising from liquidation and restructuring procedures. Debt-equity conversions would dilute shareholders' equity.

${ }^{18}$ See Haug (2007).
} 
where the difference $\left(R R_{t}-H_{0}\right) L_{t}$, if positive, is the eventual profits from liquidation or restructuring procedures, and $\lambda$ indicates the percentage of the write-up allowed on a periodic basis. Their price at time 0 is also the expected discounted cash flows at time $t$ :

$$
\text { Call }_{0}=E_{0}^{Q}\left(\frac{\lambda}{\left(1+r_{0}\right)^{t}} \min \left(\max \left(\left(R R_{t}-H_{0}\right) L_{t}, 0\right), D_{0}-D_{t-1}\right)\right) \text {. }
$$

To price CoCos, the dynamics of the debt stock $D_{\mathrm{t}}$ at time $\boldsymbol{t}$ needs to be characterized.

The debt dynamics is driven by debt write-downs and write-ups as following:

$$
D_{t}-D_{t-1}=-\varphi \max \left(\left(H_{0}-R R_{t}\right) L_{t}, 0\right)+\lambda \min \left(\max \left(\left(R R_{t}-H_{0}\right) L_{t}, 0\right), D_{0}-D_{t-1}\right),
$$

where $D_{t}-D_{t-1}$ is the change in the debt stock at time $t$. For instance, Figure 5, Panel B illustrates the debt dynamics with two periods and two loans $L_{1}$ and $L_{2}$. The debt stock $D_{2}$ at time 2 is path dependent as it is the outcome from writing down the debt stock $D_{1}$ at time 1 by the possible incurred loss at time 2 . The recursion is important for coupon payments at time $t$, which are different according to the debt stock at time $t-1$. Given that write-offs and write-ups are priced out of the probability distribution for the random residual recovery rate $R R_{\mathrm{t}}$, the debt stock $D_{t}$ at time $t$ also has a similar probability distribution as shown in Figure 5 , panel B.

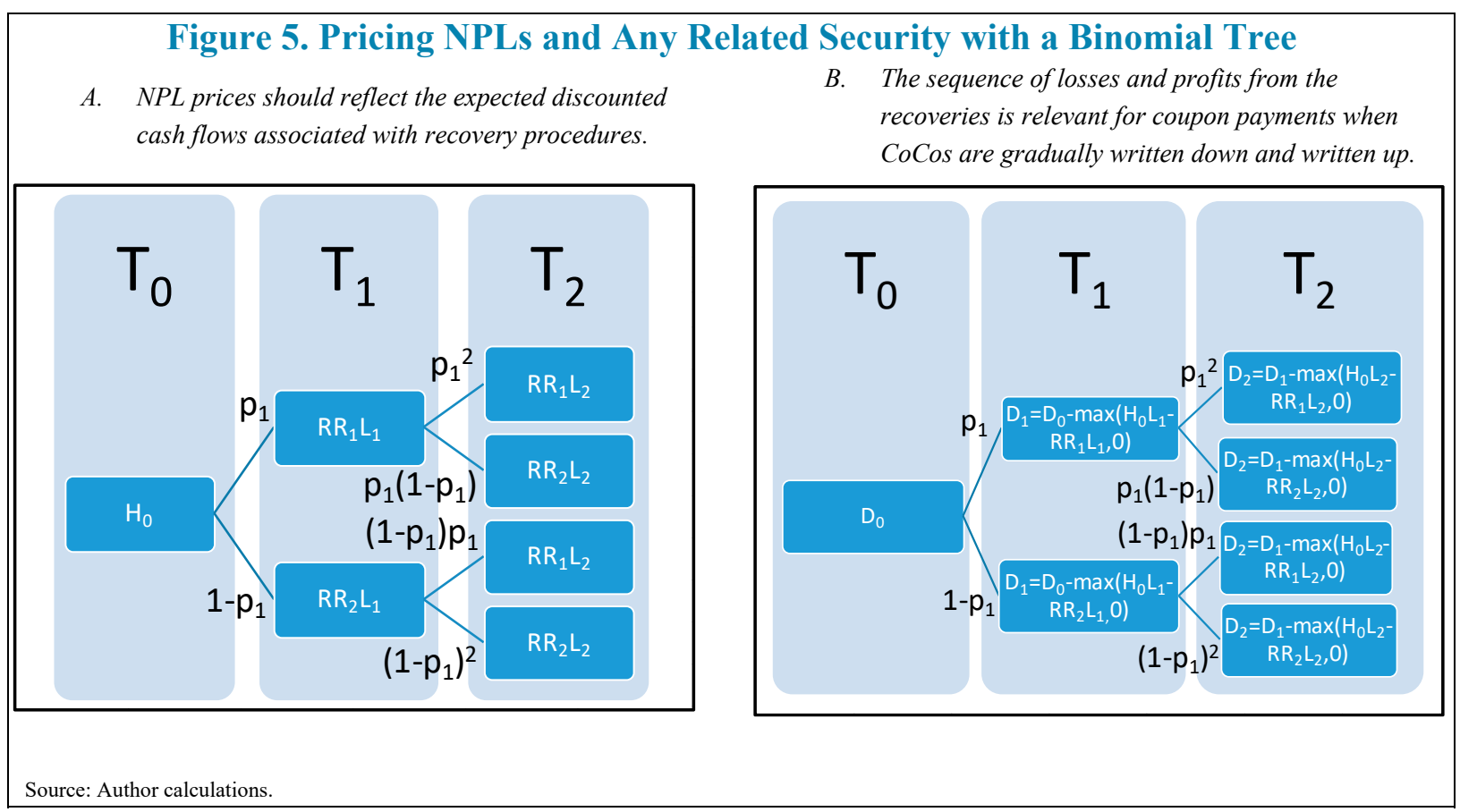


Private AMs' equity would also mirror debt write-downs and write-ups. Changes in the private AM's equity consists of losses or profits arising from the liquidation or restructuring procedures, debt write-downs, debt write-ups, coupon payments, and a term added to capture the present value of the net proceeds obtained by reinvesting the periodic cash proceeds, net of the reduction in the debt stock, at the risk-free interest rate $r_{0}$ during the period $T$ - $t$ :

$$
\begin{aligned}
& S_{t}-S_{t-1}=\left(R R_{t}-H_{0}\right) L_{t}+\varphi \max \left(\left(H_{0}-R R_{t}\right) L_{t}, 0\right)-\lambda \min \left(\max \left(\left(R R_{t}-H_{0}\right) L_{t}, 0\right), D_{0}-D_{t-1}\right) \\
& -c D_{t-1}+\left(H_{0} L_{t}+D_{t}-D_{t-1}\right)\left(\frac{\left(1+r_{0}\right)^{T-t}-1}{\left(1+r_{0}\right)^{T-t}}\right),
\end{aligned}
$$

where $S_{t}-S_{t-1}$ is the change in equity at time $t$ and $c$ is the coupon rate paid on the debt stock $D_{t-1}$ at time $t-1$.

Instead of periodic debt write-downs and write-ups, an alternative CoCo would contain clauses allowing for a debt write-down or write-up only on the maturity date $T$. As a result, the debt principal would remain constant till the maturity date $T$, yielding constant coupon payments to investors. Losses arising from liquidation procedures in one year could be covered by profits from restructuring procedures in other years. On the maturity date $T$, the debt principal would be written down in proportion to net cumulative losses $-N P_{T}$ :

$$
\text { Write }- \text { down }=-\psi \max \left(-N P_{T}, 0\right) \text {, }
$$

where $\psi$ is the percentage of write-downs allowed in the CoCo. The net cumulative recovery losses $N P_{T}$ from periods 1 to $T$ on the maturity data $T$ are driven by:

$$
N P_{T}-N P_{T-1}=\left(R R_{T}-H_{0}\right) L_{T}
$$

where:

$$
N P_{T-1}=\sum_{t=1}^{T-1}\left(R R_{t}-H_{0}\right) L_{t} .
$$

On the other hand, debt write-ups on the maturity date $T$ would provide investors with a windfall gain on the maturity date $T$. This is equivalent to a call option written on the net cumulative profits $N P_{T}$ on the maturity date $T$ :

$$
\text { Write }- \text { up }=\theta \max \left(N P_{T}, 0\right)
$$

where $\theta$ is the percentage of the write-up allowed as a windfall gain.

With debt write-downs and debt write-ups only on the maturity date $T$, the debt stock would remain constant at the initial stock $D_{0}$ till time $\boldsymbol{T}$-1. There are no periodic writedowns or write-ups till date $T-1$. On the maturity date $T$, the debt stock $D_{T}$ at time $T$ would then be written down or written up according to: 


$$
D_{T}-D_{T-1}=-\psi \max \left(-N P_{T}, 0\right)+\theta \max \left(N P_{T}, 0\right),
$$

while the change $S_{T-} S_{T-1}$ in the private AM's equity at time $T$ would be given by:

$$
S_{T}-S_{T-1}=\left(R R_{T}-H_{0}\right) L_{T}+\psi \max \left(-N P_{T}, 0\right)-\theta \max \left(N P_{T}, 0\right)-c D_{0},
$$

In the model, both prices of a CoCo and an equity participation in private AMs are also the present value of the expected discounted cash flows. The price $P b_{0}$ of a $\mathrm{CoCo}$ at time 0 is then, under a risk-neutral distribution, given by the expected discounted cash flows:

$$
P b_{0}=E_{0}^{Q}\left(\sum_{t=1}^{T} \frac{c D_{t-1}}{\left(1+r_{0}\right)^{t}}+\frac{D_{T}}{\left(1+r_{0}\right)^{T}}\right),
$$

where the debt stock $D_{t}$ at time $t$ is given by equations (13) or (19) above. Similarly, the price $P e_{0}$ of an equity participation at time 0 under a risk-neutral probability distribution is also given by the expected discounted cash flows:

$$
P e=E_{0}^{Q}\left(\sum_{t=1}^{T} \frac{S_{t}-S_{t-1}}{\left(1+r_{0}\right)^{t}}\right),
$$

where the change $S_{t}-S_{t-1}$ in the private AM's equity is given by equations (14) or (20).

\section{RESULtS}

Pricing CoCos with multiple options to write down and write up principal requires all potential cash flow paths associated with liquidation and restructuring. The maturity date $T$ is set at 10 years. A single-name portfolio consisting of 67 loans unevenly dispersed through time is used to price CoCos, with a minimum of five loans per period, inverted cash flows, and a four-year average duration as shown in Figure $6 .{ }^{19}$ This implies that there are at least 32 permutations for pricing the many options and that convergence of option prices is assured. ${ }^{20}$ Another related assumption is that liquidations and restructurings occur throughout the year, with losses or profits either reducing or augmenting, respectively, the debt principal at the end of each year-implying 10 put and 10 call options to write down losses and write up profits, respectively - or on the maturity date in the case of cumulative net losses or profits - implying one put and one call option at the end of the tenth year. In addition,

\footnotetext{
${ }^{19}$ The amounts per period are based on the gross estimated remaining collection by Hoist Finance, B2Holding, Intrum-Justitia, and GFKL available in their 2016 investor presentation or annual reports.

${ }^{20}$ See Hull (2002).
} 
interest is paid at the end of each year and the remaining principal is repaid at the end of the tenth year.

Given the limited publicly available information on residual recovery rates in the Portuguese distressed debt market, the framework is calibrated with Montepio's transfer prices and residual recovery rates. The coupon rate $c$ and the risk-free rate $r_{0}$ are set at 3.5 percent, the discount rate used by DBRS in rating Montepio's NPL securitization. This implies that straight coupon bonds are initially priced at par. The transfer price $H_{0}$ is set at 30.4 percent of GBV while the residual recovery rates $R R_{1}$ and $R R_{2}$ are 21.7 percent and 69.0 percent, respectively. ${ }^{21}$ The risk-neutral probability $p_{1}$ can then be obtained by setting the transfer price $H_{0}$ equal to expected discounted residual cash recoveries under liquidation and restructuring procedures and solving equation (8) numerically for $p_{1}$.

\section{However, bid and ask prices by private AMs and banks might not be consistent with the underlying residual recovery rates. To reflect frictions in NPL markets, bid and ask prices are assumed to be different from the transfer price $H_{0}$ consistent with the underlying residual recovery rates $R R_{1}$ and $R R_{2}$. Firstly, bid prices are assumed to be higher to reflect capital-constrained banks while the underlying residual recovery rates $R R_{1}$, and $R R_{2}$ and the risk-neutral probability $p_{1}$ remain the same. ${ }^{22}$ The higher bid prices are then used to assess the trade-off between equity and debt and the protection provided by debt write-downs against losses. Secondly, ask prices are assumed to be lower as a result of asymmetric information, lack of available high-quality data on collateral, or ineffective frameworks for debt recovery and collateral enforcement, while underlying residual recovery rates $R R_{1}$, and $R R_{2}$ and the risk-neutral probability $p_{1}$ also remain unchanged. This will trigger the mechanism provided by the call options to share the profits arising from the liquidation and restructuring procedures.}

\footnotetext{
${ }^{21}$ These are the result of gross recovery rates under liquidation and restructuring procedures of 36.7 percent and 77.2 percent net of recovery costs of 15 percent and 7.5 percent, respectively, where the 77.2 gross recovery rate under restructuring procedures was the 50 percentile gross recovery rate for non-defaulted retail loans in EBA banks with exposures to Portugal as of end-September 2017. It is assumed that recovery costs under restructuring procedures are half the ones under liquidation procedures.

${ }^{22}$ Fell, Grodzicki, Martin, and O’Brien (2016) analyze factors affecting both the demand and supply of NPLs.
} 
Figure 6. Gross Loans Under Liquidation or Restructuring till Maturity Date (In percent of GBV)

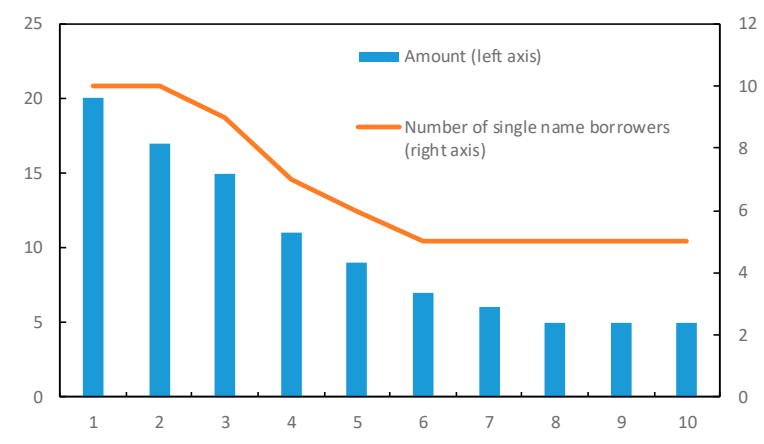

Finally, the residual recovery rate $R_{1}$ from liquidation procedures could also improve because of judicial reforms. The impact of improvements in liquidation procedures is tested by increasing the liquidation residual recovery rate $R R_{1}$ by 15 percentage points from 21.7 percent to 36.7 percent. If the liquidation probability $p_{1}$ remains unchanged, the transfer price $H_{0}$ would increase from 30.4 percent of GBV to 39.9 percent. Judicial reforms that help enforce claims and facilitate bankruptcies and foreclosures are essential to improve the prospect of higher liquidation residual recovery rates.

Given the assumptions above and the percentages $\varphi, \lambda, \psi$, and $\theta$ of losses or profits that are written down or written up respectively, CoCos and private AM's equity can be priced out of the model in the previous section. Table 3, Panel A summarizes the results of pricing CoCos and private AM's equity with the transfer price $H_{0}$ that is consistent with the underlying residual recovery rates $R R_{1}$ and $R R_{2}$ while Panels $\mathrm{B}$ and $\mathrm{C}$ report the results with bid and ask prices that are above and below the transfer price $H_{0}$, respectively. The top part of each column contains the assumptions about the combination and the percentages $\varphi, \lambda, \psi$, and $\theta$ of write-downs and write-ups, which are assumed to be 100 percent. ${ }^{23,24}$ The bottom part of each column shows the results of pricing $\mathrm{CoCos}\left(\mathrm{Pb} b_{0}\right)$ and private AM's equity $\left(\mathrm{Pe}_{0}\right)$ under the different assumptions.

With the transfer price $H_{0}$ consistent with the underlying residual recovery rates $R R_{1}$ and $\boldsymbol{R} \boldsymbol{R}_{2}$, the put and call options would reallocate value between investors and private AMs. Panel A, Column 1 indicates that straight coupon bonds with similar coupon and riskfree discount rates are priced at par. Since the underlying residual recovery rates $R R_{1}$ and $R R_{2}$ remain unchanged throughout all columns, the probability $p_{1}$ associated with liquidations is above 70 percent, implying a low probability to recover NPLs in restructuring procedures.

\footnotetext{
${ }^{23}$ Yearly write-ups are capped by the initial debt amount.

${ }^{24}$ The simulations with 100 percent provide an upper bound of the effects of write-downs and write-ups on CoCos and private AMs' equity.
} 
Yearly write-downs would slightly reduce Cocos' price $P b_{0}$ below the price $H_{0}$ (Panel A, Column 2) as losses arising from low recoveries would reduce the debt principal and lower interest payments. The yearly-capped power options in CoCos would provide banks with some relieve but not enough to fully offset debt write-downs from losses (Panel A, Column 3). Moreover, the write-down on the maturity date (Panel A, Column 4) would allow for a larger period to offset lower cash recoveries with higher ones over the life of the bond, with a positive impact on CoCo prices. Finally, CoCos with write-downs and write-ups on the maturity date (Panel A, Column 5) would benefit banks as net cumulative recoveries above the transfer price $H_{0}$ would add to the debt principal. To offset lower or higher coupon payments and set CoCo prices at par, the coupon rate $C$ could then be raised (Panel A, Columns 2 to 4) or lowered (Panel A, Column 5), respectively, as suggested in the last row of Panel A.

NPL sales at higher bid prices than the transfer price $H_{0}$ that is consistent with the underlying recovery rates could result in large losses to private AMs. When bonds are issued with no embedded options, all losses are incurred by private AMs (Panel B, Column 1). Yearly debt write-downs in CoCos would then mitigate the effect of large losses on private AMs' equity with an offsetting increase in equity associated with a decline in debt principal (Panel B, Column 2). Moreover, yearly write-ups and write-downs or on the maturity date $T$ (Panel B, Columns 3 to 5) would be less beneficial to private AMs since some value is reallocated to CoCos and investors. The coupon rate $c$ could then be lowered (Panel B, Columns 1 to 5) to offset high coupon payments arising from a higher debt principal and reduce the excess of CoCo prices over par.

Similarly, NPL sales at lower ask prices than the transfer price $H_{0}$ consistent with the underlying recovery rates could result in large profits to private AMs. Panel $\mathrm{C}$, Column 1 indicates that private AMs would benefit from lower ask prices. Private AMs could share the gains from higher residual recovery rates with investors when CoCos contain a debt write-up on the maturity date (Panel C, Column 5). On the other hand, the yearly capped power options (Panel C, Column 3) are only triggered throughout the maturity date when the lower ask price is in the interval between the residual recovery rate $R R R_{1}$ under liquidation and the transfer price $H_{0}$. The coupon rate $c$ could then be raised (Panel $\mathrm{C}$, Columns 1 to 4 ) to offset low coupon payments arising from a lower debt principal and reduce the difference resulting from CoCo prices below par. On the other hand, the coupon rate $c$ could be lowered (Panel $\mathrm{C}$, Column 5) to offset high coupon payments when CoCo prices are above par. ${ }^{25}$

\footnotetext{
${ }^{25}$ Another possibility is to reduce the percentage of gains to be written up.
} 


\section{Table 3. Impact of Debt Write-Downs and Debt Write-ups on Private Asset Managers}

Assumptions include: (i) time to maturity $T$ of ten years; (ii) residual recovery rates $R R_{1}$ and $R R_{2}$ under under liquidation and restructuring procedures of 21.7 percent and 69.0 percent, respectively; (iii) coupon $C$ and risk-free $r_{0}$ interest rates of 3.5 percent; (iv) a portfolio with 67 single-name borrowers; and (v) gross loans of of $€ 100.00$.

A. Sale price $H_{0}$ of 30.4 percent consistent with underlying residual recovery rates $R R_{1}$ and $R R_{2}$.

\begin{tabular}{|c|c|c|c|c|c|}
\hline & (1) & $(2)$ & (3) & (4) & (5) \\
\hline \multicolumn{6}{|l|}{ Additional assumptions } \\
\hline Yearly write-downs & & V & v & & \\
\hline$\varphi$ (in percent) & & 100 & 100 & & \\
\hline Yearly write-ups & & & V & & \\
\hline$\lambda$ (in percent) & & & 100 & & \\
\hline End-of-period write-down & & & & V & V \\
\hline$\psi$ (in percent) & & & & 100 & 100 \\
\hline End-of-period write-up & & & & & V \\
\hline$\theta$ (in percent) & & & & & 100 \\
\hline Results & & & & & \\
\hline$p_{1}$ (in percent) & 72.3 & 72.3 & 72.3 & 72.3 & 72.3 \\
\hline (i) $P b$ (debt, in euros) & 30.40 & 28.85 & 29.97 & 30.34 & 33.53 \\
\hline (ii) $P e$ (equity, in euros) & 0.00 & 1.55 & 0.43 & 0.06 & -3.13 \\
\hline (iii) $P b_{0}+P e_{0}$ (total, in euros) & 30.40 & 30.40 & 30.40 & 30.40 & 30.40 \\
\hline$C_{P e=0}$ (adjusted coupon rate, in percent) $1 /$ & 3.50 & 4.13 & 3.67 & 3.52 & 2.26 \\
\hline
\end{tabular}

B. Bid price of 40.4 percent, which is above the transfer price $H_{0}$ consistent with underlying residual recovery rates $R R_{1}$ and $R R_{2}$.

\begin{tabular}{|c|c|c|c|c|c|}
\hline & $(1)$ & (2) & (3) & (4) & (5) \\
\hline \multicolumn{6}{|l|}{ Additional assumptions } \\
\hline Yearly write-downs & & V & V & & \\
\hline$\varphi$ (in percent) & & 100 & 100 & & \\
\hline Yearly write-ups & & & V & & \\
\hline$\lambda$ (in percent) & & & 100 & & \\
\hline End-of-period write-down & & & & V & V \\
\hline$\psi$ (in percent) & & & & 100 & 100 \\
\hline End-of-period write-up & & & & & V \\
\hline$\theta$ (in percent) & & & & & 100 \\
\hline Results & & & & & \\
\hline $\mathrm{p}_{1}$ (in percent) & 72.3 & 72.3 & 72.3 & 72.3 & 72.3 \\
\hline$P b_{0}$ (debt, in euros) & 40.40 & 34.03 & 35.10 & 36.40 & 36.44 \\
\hline$P e_{0}$ (equity, in euros) & -10.00 & -3.63 & -4.70 & -6.00 & -6.04 \\
\hline$P b_{0}+P e_{0}$ (total, in euros) & 30.40 & 30.40 & 30.40 & 30.40 & 30.40 \\
\hline$C_{P e=0}$ (adjusted coupon rate, in percent) $1 /$ & 0.53 & 2.30 & 1.97 & 1.72 & 1.70 \\
\hline
\end{tabular}




\section{Table 3. Continued}

C. Ask price of 25.4 percent, which is below the transfer price $H_{0}$ consistent with underlying residual recovery rates $R R_{1}$ and $R R_{2}$.

\begin{tabular}{|c|c|c|c|c|c|}
\hline & (1) & $(2)$ & (3) & (4) & (5) \\
\hline \multicolumn{6}{|l|}{ Additional assumptions } \\
\hline \multicolumn{6}{|l|}{ Yearly write-downs } \\
\hline \multicolumn{6}{|l|}{$\varphi$ (in percent) } \\
\hline \multicolumn{6}{|l|}{ Yearly write-ups } \\
\hline \multicolumn{6}{|l|}{$\lambda$ (in percent) } \\
\hline \multicolumn{6}{|l|}{ End-of-period write-down } \\
\hline & & & & 100 & 100 \\
\hline End-of-period write-up & & & & & V \\
\hline \multicolumn{6}{|l|}{$\theta$ (in percent) } \\
\hline \multicolumn{6}{|l|}{ Results } \\
\hline $\mathrm{p}_{1}$ (in percent) & 72.3 & 72.3 & 72.3 & 72.3 & 72.3 \\
\hline$P b_{0}$ (debt, in euros) & 25.40 & 24.96 & 25.34 & 25.40 & 32.08 \\
\hline$P e_{0}$ (equity, in euros) & 5.00 & 5.44 & 5.06 & 5.00 & -1.68 \\
\hline$P b_{0}+P e_{0}$ (total, in euros) & 30.40 & 30.40 & 30.40 & 30.40 & 30.40 \\
\hline$C_{P e=0}$ (adjusted coupon rate, in percent) $1 /$ & 5.87 & 6.10 & 5.90 & 5.87 & 2.71 \\
\hline
\end{tabular}

1 / Coupon rate that sets the sum of the prices of CoCos and equity $P b_{0}$ and $P e_{0}$ equal to the $H_{0}$. Source: Author calculations.

Finally, improvements in the residual recovery rate $R_{1}$ have a positive effect on the transfer price $\boldsymbol{H}_{\mathbf{0}}$. Table 4 shows the results of a scenario with the higher residual recovery rate $R R_{1}$ in liquidations. Given the 72.3 percent probability $p_{1}$, the 69 percent residual recovery rate $R R_{2}$ under restructuring procedures, and the 3.5 percent coupon and risk-free interest rates $c$ and $r 0$, an increase in the liquidation residual recovery rate $R R_{1}$ from 21.7 percent to 36.7 percent is reflected in an increase in the transfer price $H_{0}$ from 30.4 percent to 39.9 percent. Put and call options would then reallocate the additional value (Columns 2 to 4 ) created by an improvement in liquidation residual recovery rates. Put options to write down losses would benefit private AMs (Column.2) by subtracting value from investors while call options to write up profits would work in favor of investors (Columns 3 and 5). 
Table 4. Impact of Improvements in the Net Recovery Rate Under Liquidation Procedures on Private Asset Managers

Assumptions include: (i) time to maturity $T$ of ten years; (ii) residual recovery rates

$R R_{1}$ and $R R_{2}$ under liquidation and restructuring procedures of 21.7 percent and 69.0

percent respectively; coupon $C$ and risk-free interest $r$ rates of 3.5 percent; (iv) a portfolio with 67 single-name borrowers; and (v) gross loans of $€ 100.00$.

\begin{tabular}{|c|c|c|c|c|c|}
\hline Results & (1) & (2) & (3) & (4) & (5) \\
\hline Yearly write-downs & & V & V & & \\
\hline$\varphi$ (in percent) & & 100 & 100 & & \\
\hline Yearly write-ups & & & v & & \\
\hline$\lambda$ (in percent) & & & 100 & & \\
\hline End-of-period write-down & & & & V & V \\
\hline$\psi($ in percent) & & & & 100 & 100 \\
\hline End-of-period write-up & & & & & V \\
\hline$\theta$ (in percent) & & & & & 100 \\
\hline Results & & & & & \\
\hline$p_{1}$ (in percent) & 72.3 & 72.3 & 72.3 & 72.3 & 72.3 \\
\hline (i) $\mathrm{Pb}$ (debt, in euros) & 39.86 & 39.46 & 39.80 & 39.86 & 43.97 \\
\hline (ii) Pe (equity, in euros) & 0.00 & 0.40 & 0.06 & 0.00 & -4.11 \\
\hline (iii) $P b_{0}+P e_{0}$ (total, in euros) & 39.86 & 39.86 & 39.86 & 39.86 & 39.86 \\
\hline
\end{tabular}

Source: Author calculations. 


\section{CONCLUding ReMARKS}

Lessons from NPL sales in selected European countries can be drawn to incentivize banks and investors in Portugal. Successful private AMs have required a supporting environment with an effective legal system, a sound regulatory and supervisory framework, a neutral tax framework, and stable macroeconomic conditions. While the different pace of sales in Ireland, Spain, Italy, and Portugal can be partially traced back to different factors, the high coverage and capital ratios in Spanish, Italian, and Irish banks played a role in facilitating large sales. Capital buffers and provisions in Portuguese banks have increased since 2016 and are comparable to other Italian and Spanish banks as of end-June 2018. The latest NPL transactions in the Portuguese distressed debt markets suggest higher capital and coverage ratios in Portuguese banks will further encourage larger NPL sales.

CoCos provide investors and private AMs with flexibility to reallocate risks and benefits arising from liquidation and restructuring of NPLs. These securities would be issued by private AMs - established by private equity investors and/or banks - to acquire NPLs from Portuguese banks. The paper develops a model based on NPLs transfer prices and residual recovery rates to assess private AMs' capital structures consisting of equity and CoCos. The latter would contain put and call options to write down losses and write up profits, respectively, arising from liquidation and restructuring procedures. The protection mechanism provided by debt write-downs embedded in CoCos and the incentives provided by debt write-ups could help bridging the gap between Portuguese banks' NPL bid prices and private equity firms' ask prices, increasing not only the number of transactions but also the transparency in the market. Portuguese banks would benefit from CoCos by reducing their NPL stock while private AMs would be able to expand their purchases with debt, leveraging up their capital. 


\section{REFERENCES}

Antunes, A., and N. Ribeiro, 2004, "Estimates of Expected Losses in Credit Portfolios - An Application of Survival Analysis to Firms with Default Credit," Financial Stability Report (Lisbon: Banco de Portugal), pp 145-154.

Avgouleas, E., and C. Goodhart, 2017, "Utilizing AMCs to Tackle the Eurozone's Legacy Nonperforming Loans," European Economy, No. 3(1), pp. 97-112.

Banca IFIS, 2017, Market Watch NPL: The Italian Scenario, July.

Bank of Italy, 2017, Financial Stability Report no. 1 (Rome: Bank of Italy).

BDO, 2017, IFRS in Practice: Accounting for Convertible Notes, (Brussels: BDO).

Ciavoliello, L. G., F. Ciocchetta, F. M. Conti, I. Guida, A. Rendina, and G. Santini, 2016, "What is the Value of NPLs?," Notes on Financial Stability and Supervision, no. 3. (Rome: Bank of Italy).

Ciocchetta, F., F. M. Conti, R. De Luca, I. Guida, A. Rendina, and G. Santini, 2017, "Bad Loan Recovery Rates," Notes on Financial Stability and Supervision no. 7. (Rome:

Bank of Italy).

Carlisle, A and J.M. Poilpre, 2017, Capital Struture: Issuance of GACS-Guaranteed NPL ABS Unlikely to Gain Momentun; NPL-Hungry PE and Hedge Funds May Refinance Portfolios via $A B S$, Capital Structure.

Deloitte, 2017, Shifting Momentum: Regulation Driving changes in European Loan Portfolio Markets.

Erzegovesi, L., 2017, The V\&V Plan: Slow Bank Rescuing, (http://pane-efinanza.it/2017/07/08/the-vv-plan-slow-bank-rescuing/).

European Commission, 1999, "Commission Decision of 29 July 1998 Giving Conditional Approval to the Aid Granted by Italy to Banco di Napoli," Official Journal of the European Communities, L116, pp. 36-56.

FitchRatings, 2015, "Italian Resolution Approach is Costly for Banking Sector," Press Release, November 2015.

Fell, J., J. Grodzicki, R. Martin, and E. O’Brien, 2016, “Addressing Market Failures in the Resolution of Nonperforming Loans in the Euro Area," Financial Stability Review, November, pp. 134-46 (Frankfurt: European Central Bank).

Fell, J., C. Moldovan, and E. O’Brien (2017), 2017, "Resolving Nonperforming Loans: A Role for Securitization and Other Financial Structures?" Financial Stability Review, March, pp. 158-74, (Frankfurt: European Central Bank). 
Guo, X., R. A. Jarrow, and L. Haizhi, 2008, "Distressed Debt Prices and Recovery Rate Estimation," Review of Derivatives Research, Vol. 11(October), pp. 171-204.

Hoist Finance, 2016, 2016 Investor Day Presentation, September 15.

Haug, E. G., 2007, The Complete Guide to Option Pricing Formulas, (New York: McGraw- Hill).

Hull, J. C., 2002, Options, Futures, and Other Derivatives, (New Jersey: Prentice Hall).

Journal dos Negocios, 2019, Maiores Bancos Desfizeram-se de pelo menos 5.719 Milhões em Crédito Malparado, (https://www.jornaldenegocios.pt/empresas/banca---

financas/detalhe/maiores-bancos-desfizeram-se-de-pelo-menos-5719-milhoes-em-creditomalparado?ref $=$ Not $\% \mathrm{C} 3 \%$ ADcias $\% 20 \mathrm{no}^{2} \% 20 \mathrm{Minuto}$ outros $)$.

Jung, H., 2012, “Pricing of Contingent Convertibles," Wharton Research Scholars, No. 4.

Krebel, M., 2010, "Pricing Distressed CDOs with Base Correlation and Stochastic

Recovery," UniCredit \& Universities Working Paper Series No. 01.

Maglio, R., 2016, “(Not So) Bad Bank: I Primi Venti Anni della S.G.A. del Banco di Napoli," Paradox, no. 3.

Oitante, 2017, 2015 Relatório de Gestão e Contas, (Lisbon: Oitante).

Pennachi, G. And A. Tchistyi (2018), "Contingent Convertibles with Stock Price Triggers: The Case of Perpetuities," Review of Financial Studies.

O'Kane, 2011, "Approximating Independent Loss Distributions with an Adjusted Binomial Distribution,” The Journal of Credit Risk, Vol, 7(4), pp. 103-117. 